\title{
Evaluation of milk powder quality by protein oxidative modifications ${ }^{1,2}$
}

\author{
Dana Scheidegger, ${ }^{*}$ Paola M. Radici,* Víctor A. Vergara-Roig,† Noelia S. Bosio," Silvia F. Pesce,‡ \\ Rolando P. Pecora,§\# José C. P. Romano,\# and Silvia C. Kivatinitz ${ }^{*}$ \\ *Departamento de Química Biológica (CIQUIBIC), Facultad de Ciencias Químicas, Universidad Nacional de Córdoba, Ciudad Universitaria, \\ 5000 Córdoba, Argentina \\ †Departamento de Química, Facultad de Ciencias Exactas y Naturales, Universidad Nacional de Catamarca, 4700 San Fernando del Valle \\ de Catamarca, Catamarca, Argentina \\ ‡Centro de Química Aplicada (CEQUIMAP), Facultad de Ciencias Químicas, Universidad Nacional de Córdoba, Ciudad Universitaria, \\ 5000 Córdoba, Argentina \\ §Departamento de Química Industrial y Aplicada, Facultad de Ciencias Exactas, Físicas y Naturales, Universidad Nacional de Córdoba, \\ Ciudad Universitaria, 5000 Córdoba, Argentina \\ \#Instituto A. P. de Ciencias Básicas y Aplicadas, Universidad Nacional de Villa María, Villa María, 5900 Córdoba, Argentina
}

\begin{abstract}
The objective of the present research was to evaluate commercially available milk powders according to their protein oxidative modifications and antioxidant capacity, and to evaluate if these characteristics are related to physical quality parameters such as dispersibility or stability during storage. Fifteen commercially processed spray-dried milk powders were evaluated: 6 whole milk powders (WMP), 4 skim milk powders (SMP), and 5 infant formula powders (IFP). Protein oxidative status was measured as protein carbonyl (PC) content, dityrosine content, and extent of protein polymerization. The level of PC was slightly lower in SMP than in WMP, whereas IFP had more than twice as much PC as WMP $(2.8 \pm 0.4,2.1 \pm 0.2$, and $6.5 \pm 1.3 \mathrm{nmol} /$ mg of protein for WMP, SMP, and IFP, respectively). No differences were detected in dityrosine accumulation. Although all the possible pairs of parameters were tested for correlations, we found that 4 parameters were linked: PC, whey content, protein aggregate level, and dispersibility. After 9 mo of storage at $-20^{\circ} \mathrm{C}$ or room temperature, all milk samples were analyzed to evaluate changes in protein oxidative status (PC, dityrosine, and protein integrity) and related parameters. Compared with the initial condition, $\mathrm{PC}$ increased in all tested samples after 9 mo of storage at $-20^{\circ} \mathrm{C}$ or at room temperature. Stored milk powders had increased PC and decreased dispersibility compared with prestorage levels. Our results highlight the importance of pro-
\end{abstract}

\footnotetext{
Received May 26, 2012.

Accepted February 4, 2013.

${ }^{1}$ In commemoration of the 50th anniversary of the Departmento de Química Biológica, Facultad de Ciencias Químicas, Universidad Nacional de Córdoba.

${ }^{2}$ This is a corrected version of the original PDF; the original version inadvertently omitted authors R. P. Pecora, J. C. P. Romano, and S. C. Kivatinitz.

${ }^{3}$ Corresponding author: skivatinitz@gmail.com
}

tein oxidative status in milk powder and its relationship to other related quality parameters, such as protein integrity and dispersibility. Our findings suggest that the understanding of such relationships could help in developing quality differentiation for different types of milk powders in the product market.

Key words: milk protein, protein oxidation, milk powder, infant formula

\section{INTRODUCTION}

Milk off-flavor has often been attributed to lipid oxidation (Biolatto et al., 2007; Lloyd et al., 2009) or to the Maillard reaction with consequent advanced glycation end products (Birlouez-Aragon et al., 2004). However, proteins, peptides, and amino acids are also susceptible to oxidative changes caused by free radicals that are manifested to a greater or lesser degree in different types of milk, depending on the quantity and type of lipids, prooxidants, antioxidants, and storage conditions (Davies, 2005; Fenaille et al., 2006; Scheidegger et al., 2010). Milk protein solubility in water could be closely related to oxidative status because oxidation enhances protein interactions and aggregation (Scheidegger et al., 2010), which lessen milk powder solubility (Thomas et al., 2004). Oligomerization and proteolysis were found in thermal treated milk (Carbonaro et al., 1998; Jovanovic et al., 2007) and UV-irradiated dairy powders (Scheidegger et al., 2010). Milk powder quality parameters are mostly related to solubility (e.g., wettability, dispersibility, and undissolved particles). These parameters are closely related to manufacturing process and storage conditions. Dairy powders are subject to oxidation during manufacturing because of the high temperatures used (Stapelfeldt et al., 1997), and spraydrying technology can induce changes in proteins that influence hydrophobicity, solubility, and denaturation (Singh and Creamer, 1991; Kalapathy et al., 1997; Ku- 
rozawa et al., 2009). In the case of infant formula powder (IFP), relationships between the oxidative status of proteins and quality parameters are more difficult to predict because IFP are prepared by mixing milk, whey proteins (that have been subjected to different thermal treatments and dehydration procedures), lipids, and (sometimes) nucleotides (Fenaille et al., 2006).

The changes that occur during storage of milk powders include protein polymerization and a decrease in solubility, with temperature and relative humidity being the predominant factors involved (Stapelfeldt et al., 1997; Gaiani et al., 2007).

The literature is sparse regarding protein oxidative alterations in milk, and the oxidative status of proteins from milk powder has not been reported because oxidative modifications have been mainly focused on lipids. For example, antioxidants used in milk powders have been evaluated for their capacity to inhibit peroxidation and prevent off-flavor development (Romeu-Nadal et al., 2007; Matumoto-Pintro et al., 2011) but not on protein oxidative modifications such as protein carbonyl (PC) or dityrosine bond formation.

Protein carbonyl formation is a consequence of the oxidation of some AA residues (mainly lysine, arginine, and proline residues), and PC can be produced via oxidative cleavage of the peptide backbone via the $\alpha$-amidation pathway or cleavage associated with the oxidation of glutamyl residues (Stadtman and Levine, 2000). Carbonyl derivatives can also be formed as a consequence of secondary reactions of some AA side chains with lipid oxidation products, such as 4-hydroxy2-nonenal (Stadtman and Levine, 2000). The formation of $\mathrm{PC}$ is highly indicative of milk protein oxidation (Fenaille et al., 2006). Moreover, it has been shown that $\mathrm{PC}$ and dityrosine levels increase as a consequence of thermal treatments or photo-oxidation in milk samples exposed to UV or fluorescent light (Scaloni et al., 2002; Scheidegger et al., 2010), whereas isolated milk proteins show significant variability in sensitivity to photooxidation (Dalsgaard et al., 2007).

The goal of this study was to test the relationships between protein oxidative modifications and antioxidant capacity with physical quality parameters of milk powders such as dispersibility or stability during storage. The understanding of such relationships could contribute to develop quality differentiation between different types of milk powders.

\section{MATERIALS AND METHODS}

Guanidine hydrochloride (ultrapure) was obtained from Genbiotech (Buenos Aires, Argentina). Trichloroacetic acid, glacial acetic acid, gallic acid, ethyl acetate, ethyl alcohol, and hydrochloric acid were purchased from Cicarelli (Buenos Aires, Argentina). Acrylamide, 2,4-dinitrophenylhydrazine (DNPH), and 2,2-diphenyl-1-picrylhydrazyl (DPPH) were purchased from Sigma-Aldrich (Steinheim, Germany). $N, N^{\prime}$-Methylenebis-acrylamide and acrylamide were from Sigma Chemical Co. (St. Louis, MO). All products were of analytical grade.

\section{Dairy Powders}

Fifteen commercially processed spray-dried milk and formula powders were studied. Milks were purchased from SanCor Cooperativas Unidas Limitada (Sunchales, Argentina), La Serenísima Mastellone Hermanos S.A. (General Rodríguez, Argentina), Nestlé Argentina S.A. (Villa Nueva, Argentina), and La Sibila (Nogoyá, Argentina). Table 1 shows the physicochemical characteristics of the individual samples. Fat content was determined by the Rose-Gottlieb method (AOAC International, 2005; method 989.05), protein content by the Kjeldahl method (AOAC International, 2005; method 930.29), moisture by drying at $100^{\circ} \mathrm{C}$ for $2 \mathrm{~h}$ according to AOAC International (2005; method 931.04), and wettability and dispersibility according to FIL Standard (International Dairy Federation, 1979; FIL-IDF 87:1979). Milk powders samples were stored at $24^{\circ} \mathrm{C}$ (warm storage, WS) or $-20^{\circ} \mathrm{C}$ (cold storage, CS) for 9 mo in the dark.

\section{Color Measurement}

Evaluation of color was carried out using a spectrophotometer (model CM 600d, Konica Minolta, Tokyo, Japan) according to the CIE Lab Scale. For each sample, $\mathrm{L}$ (brightness), a ( - green to + red component) and $\mathrm{b}$ (- blue to + yellow component) parameters were measured for all samples. The instrumental settings were a D65 artificial daylight (10 ${ }^{\circ}$ standard angle). Each reported color value was the mean of 3 determinations at $25^{\circ} \mathrm{C}$.

\section{Protein UV-Visible Spectral Analyses}

Proteins from reconstituted milk (1 $\mathrm{mg}$ of protein) were precipitated with $10 \%$ (wt/vol) TCA (final concentration) and recovered by centrifugation for $5 \mathrm{~min}$ at $7,500 \times g$ (Micromax RF centrifuge, International Equipment Company, Needham, MA). Protein pellets were washed 3 times with $1 \mathrm{~mL}$ of ethanol:ethyl acetate 50:50 ( $\mathrm{vol} / \mathrm{vol})$, and redissolved in $1 \mathrm{~mL}$ of 6 $M$ guanidine hydrochloride, $\mathrm{pH} 7$. Spectral data were obtained (200-600 nm) using a Mini Spec UV-visible spectrophotometer (Shimadzu, Kyoto, Japan). The ratio of whey protein to total milk protein was calculated 
Table 1. Composition and quality parameters ${ }^{1}$

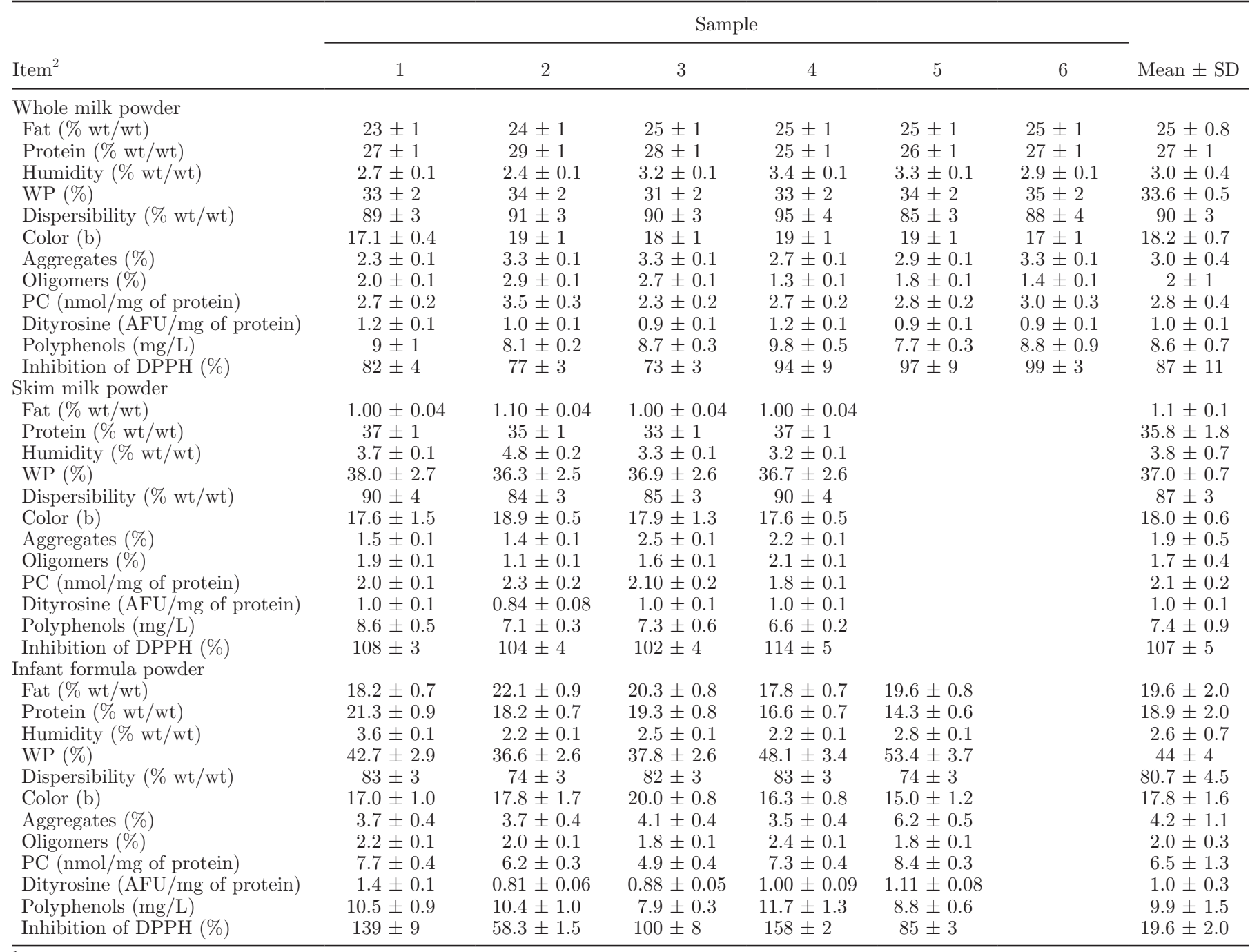

${ }^{1}$ Fifteen commercially processed spray-dried milk powders were studied: 6 whole milk, 4 skim milk, and 5 infant formula powder samples. Each determination was carried out in quadruplicate, and significant differences were analyzed by a paired $t$-test.

${ }^{2} \mathrm{WP}=$ whey protein; $\mathrm{PC}=$ protein carbonyl; AFU = arbitrary fluorescence units; $\mathrm{DPPH}=2,2$-diphenyl-1-picrylhydrazyl.

using the UV fourth-derivative absorption spectroscopy method (Lüthi-Peng and Puhan, 1999).

\section{Determination of PC}

The procedure was adapted from previously reported methods (Levine et al., 1990; Fenaille et al., 2006). An aliquot of aqueous milk solution (1 $\mathrm{mg}$ of protein) was incubated with $10 \mathrm{mM}$ DNPH in $2 \mathrm{M} \mathrm{HCl}(1 \mathrm{~mL}$ volume), for $30 \mathrm{~min}$ at room temperature $\left(24^{\circ} \mathrm{C}\right)$. Milk proteins were precipitated with $10 \%$ (wt/vol) TCA (final concentration) and recovered by centrifugation for $5 \mathrm{~min}$ at 7,500 $\times g$ (Micromax RF centrifuge, International Equipment Company). Protein pellets were washed 3 times with $1 \mathrm{~mL}$ of ethanol:ethyl acetate 50:50 (vol/vol) to remove free DNPH reagent and redissolved in $1 \mathrm{~mL}$ of $6 \mathrm{M}$ guanidine hydrochloride, $\mathrm{pH}$ 2.3. Protein carbonyls were determined by UV spectrophotometry $\left(\varepsilon_{370 \mathrm{~nm}}=2.2 \times 10^{4} \mathrm{M}^{-1} \mathrm{~cm}^{-1}\right.$, where $\varepsilon=$ molar absorptivity), with a Mini Spec UV-vis spectrophotometer (Shimadzu). Results were expressed as nanomoles of carbonyl per milligram of protein. Each determination was carried out in quadruplicate.

\section{Dityrosine Quantification}

Protein (1 mg) from reconstituted milk was precipitated with $10 \%$ (wt/vol) TCA (final concentration) and recovered by centrifugation for $5 \mathrm{~min}$ at $7,500 \times$ $g$ (Micromax RF centrifuge, International Equipment 
Company). Protein pellets were redissolved in $1 \mathrm{~mL}$ of $6 M$ guanidine hydrochloride $\mathrm{pH} 7$. Protein solutions were analyzed for the presence of dityrosine by fluorometry, and measurements were made using an SLM 4800C fluorometer (SLM/Aminco, American Instrument Company, Urbana, IL) equipped with a xenon-arc lamp using an 8-nm bandwidth. Formation of dityrosine was monitored by the increase in fluorescence using excitation and emission wavelengths of 315 and 410 $\mathrm{nm}$, respectively, as reported previously (Scheidegger et al., 2010). Dityrosine has a characteristic emission spectrum of authentic standard with a maximum at $410 \mathrm{~nm}$ (Capeillere-Blandin et al., 1991). Dityrosine was calculated from the ratio of emission intensities $410 \mathrm{~nm}$ and $350 \mathrm{~nm}$, and expressed as arbitrary fluorescence units. Each determination was carried out in quadruplicate.

\section{Total Phenolic Content}

Total phenolic content of milk samples was determined according to Folin-Ciocalteu spectrophotometric method (Singleton and Rossi, 1965) with some modifications. Milk samples $(0.015 \mathrm{~mL})$ were diluted to 2.5 $\mathrm{mL}$ with deionized water and mixed with $0.100 \mathrm{~mL}$ of $1 \mathrm{~N}$ Folin-Ciocalteu's phenol reagent and allowed to react for $8 \mathrm{~min}$. Then, $0.100 \mathrm{~mL}$ of $20 \%$ (wt/vol) $\mathrm{Na}_{2} \mathrm{CO}_{3}$ solution was added. After incubation at $4^{\circ} \mathrm{C}$ for $75 \mathrm{~min}$, samples were centrifuged for $30 \mathrm{~min}$ at 10,000 $\times g$ and $4^{\circ} \mathrm{C}$. The supernatants were transferred into a 1.5-mL cuvette (1-cm path length), and absorbance at $765 \mathrm{~nm}$ was determined using a Mini Spec UV-vis spectrophotometer (Shimadzu). Extract concentrations were calculated using a gallic acid standard curve, equivalents were read off the straight line generated by linear regression, and the total phenolic content was expressed as milligrams of gallic acid equivalents per 1,000 $\mathrm{mL}$ of sample. The experiment was carried out in triplicate.

\section{DPPH Radical Scavenging Capacity}

The capacity to scavenge the free radical DPPH was monitored according to a previously described method (Shimada et al., 1992). Milk powder samples were prepared at different concentrations with deionized water, and $0.070 \mathrm{~mL}$ of sample was added to $0.750 \mathrm{~mL}$ of 6 $\times 10^{-4} M$ ethanolic solution of DPPH. The absorbance at $492 \mathrm{~nm}$ was measured in a multiwell plate using an RT-2100C microplate reader (Rayto, Shenzhen, China) after the solution had been allowed to stand in the dark for $30 \mathrm{~min}$ at room temperature $\left(24^{\circ} \mathrm{C}\right)$. The standard curve was made with 9 concentrations of gallic acid. Each sample was assessed in triplicate. Radical scavenging activity was expressed as the inhibition percentage of free radical by the sample and was calculated as $[1$ - (test sample absorbance/blank sample absorbance)] × 100 (Barros et al., 2007).

\section{Protein Polymerization and Proteolysis}

Polymerization and proteolysis were evaluated by PAGE under reducing conditions; SDS-PAGE was performed according to the established method for milk proteins (Jovanovic et al., 2007), using a $3 \%$ polyacrylamide stacking gel and a $15 \%$ separating gel. Before electrophoresis, milk samples were diluted 25 times in distilled deionized water, mixed with Laemmli sample buffer containing $2.5 \% \beta$-mercaptoethanol, and boiled for $5 \mathrm{~min}$ (Laemmli, 1970). The vertical electrophoresis unit Mini-Protean III system (BioRad Corp., Richmond, CA) was used in conjunction with the Bio-Rad Power PAC 3000 power supply. The gel was stained with $0.25 \%$ Coomassie Blue R-250 for 90 min, and destained in the methanol:acetic acid solution. Destained gels were scanned (Epson Stylus TX115 scanner, Capital Federal, Argentina) and quantified by densitometry analysis using the free software Image J (National Institutes of Health, Bethesda, MD).

\section{Statistical Analyses}

Data points were the mean \pm standard deviations of 3 separate experiments, each with triplicate determinations. Differences were tested by 2 -tailed $t$-test. Correlation analysis was carried out by the least-squares method. Data were analyzed using the Stat Plus software (Berk Carey, Pacific Grove, CA).

\section{RESULTS AND DISCUSSION}

\section{Composition and Quality Parameters}

The composition and physical properties of each sample of milk powder are shown in Table 1. The fat, protein, and moisture contents were as expected from the manufacturers' labels and were with the standard range.

Two methods were used to quantify the ratio of whey protein (WP) in total protein: SDS-PAGE and UV fourth-derivative absorption spectroscopy. The ratio of whey to total protein for whole milk powder (WMP) was $33.6 \pm 0.5 \%$, for skim milk powder (SMP) was $37.0 \pm 0.7 \%$ (WMP vs. SMP; $P<0.002$ ), and for IFP was $44 \pm 4 \%$ (WMP vs. IFP; $P<0.007$ ), as determined by the UV fourth-derivative absorption spectroscopy method. These data correlated well with those obtained with SDS-PAGE $(P<0.002$; data not shown). This observation is concordant with the fact that different 
dairy powder formulas have added whey protein in different proportions.

Dispersibility was significantly lower $(P<0.0025)$ for IFP than for WMP or SMP $(80.7 \pm 4.5,90 \pm 3$, and $87 \pm 3$, respectively; $P<0.03$ for IFP vs. WMP and IFP vs. SMP). No difference in color could be detected.

\section{Protein Oxidative Status}

Protein oxidative status was measured as contents of PC and dityrosine and extent of protein polymerization. Significant differences were found in the PC content for the 3 types of milk powders. The level of PC (Table 1, Figure 1A) was slightly lower in SMP than in WMP, whereas IFP had more than twice as much PC as WMP $(2.8 \pm 0.4,2.1 \pm 0.2$, and $6.5 \pm 1.3 \mathrm{nmol} /$ mg of protein for WMP, SMP, and IFP, respectively; $P \leq 0.009$ for SMP vs. WMP; $P \leq 0.0001$ for IFP vs. WMP). No differences between the 3 milk powder types were detected when oxidation was measured as accumulation of dityrosine (Table 1, Figure 1B).

A
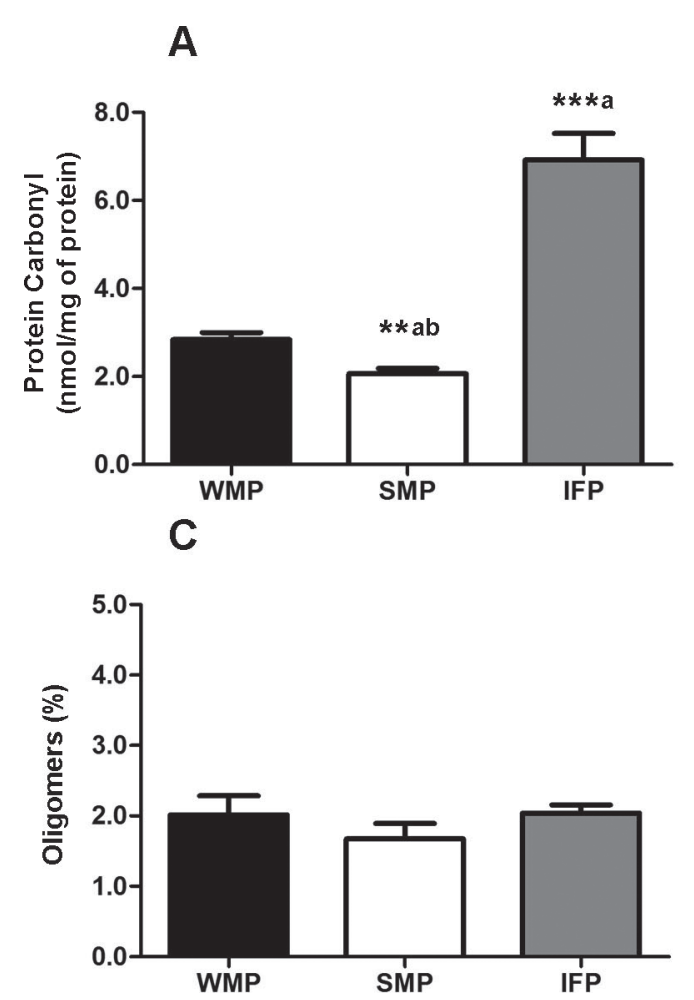

The elevated PC levels of the IFP group were in line with previous findings. For example, higher carbonyl values for IFP than for liquid milk samples had been reported (Fenaille et al., 2006). In raw and thermaltreated milk, protein-bound carbonyl content correlates positively with the severity of the heat treatment (Scaloni et al., 2002), so higher levels of PC in IFP could indicate stronger thermal conditions for IFP processing compared with that used for WMP or SMP. Differences in PC without dityrosine formation have been observed in other dairy products evaluated for oxidative damage. When Mozzarella cheese was evaluated for oxidative damage variation, PC content was altered without an observed alteration in dityrosine (Balestrieri et al., 2002).

The extent of protein polymerization was analyzed by SDS-PAGE. The levels of aggregates and oligomers were evaluated in the 3 types of powders (Figure 1C and 1D). The formation of oligomers (molecular weight $>80$ and $<175 \mathrm{kDa}$ ) was also evaluated. The SMP samples showed the lowest content of oligomers $(1.7 \pm 0.4 \%)$ although the difference was not significant (Table 1,
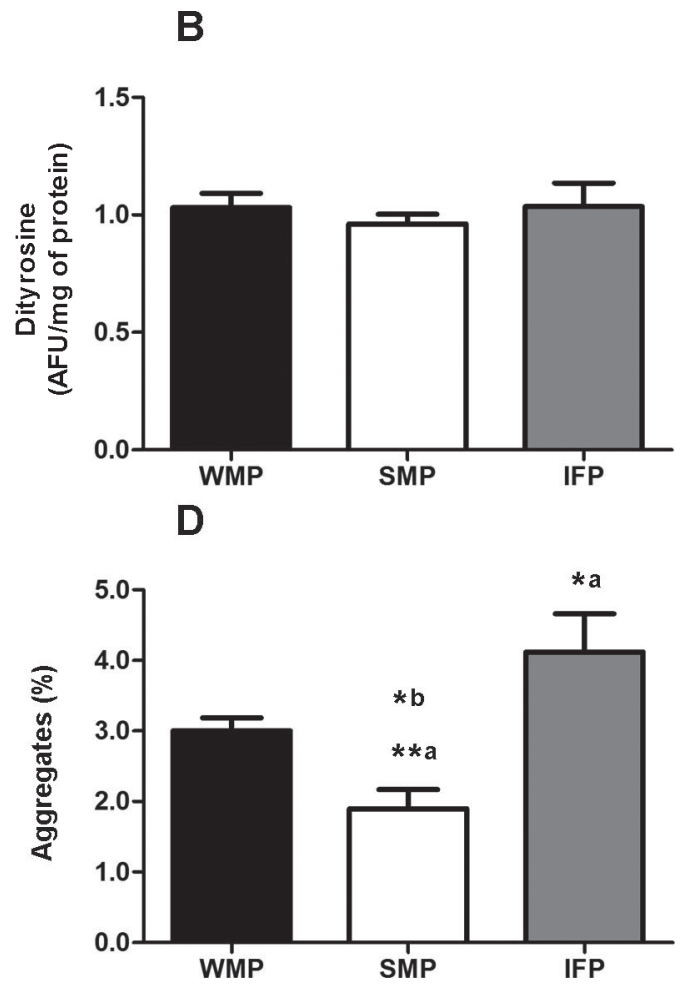

Figure 1. Protein oxidative status of whole (WMP, $\mathrm{n}=6$ ), skim (SMP, $\mathrm{n}=4$ ), and infant formula (IFP, $\mathrm{n}=5)$ milk powders: (A) protein carbonyls, (B) dityrosine, (C) protein oligomers, and (D) protein aggregates. Protein carbonyl levels were determined by the colorimetric method of Levine et al. (1990); results were expressed as nanomoles of protein carbonyl per milligram of protein. Dityrosine was determined by fluorescence spectroscopy; results were expressed as arbitrary fluorescence units (AFU) and normalized by protein content. Protein oligomer and aggregate contents were obtained from the densitometry analysis of the SDS-PAGE under reducing conditions; oligomers (molecular weights between 80 and $175 \mathrm{kDa}$ ) and aggregates (protein that did not penetrate in the staking gel) were expressed as a percentage of total protein. Analysis of variance and a $t$-test were used to determine the differences between groups: ${ }^{*} P<0.05,{ }^{* *} P<0.01,{ }^{* * *} P<0.001$; ${ }^{\mathrm{a}} \mathrm{SMP}$ or IFP versus WMP; ' $\mathrm{IFP}$ versus SMP. Each determination was carried out in quadruplicate. 
Figure 1C). The percentage of aggregates (protein that did not enter in the stacking gel) was significantly different between all the groups $(P \leq 0.05$; Table 1 , Figure 1D).

\section{Antioxidant Capacity}

Two conventional methods for determining the antioxidant activity of foods are measurements of phenolic content and radical scavenging activity. The presence of polyphenols in milk depends on the diet of the animal and may have a bioactive effect on milk component conservation (Besle et al., 2010). The radical scavenging activity of milk has been related to total lipid content, polyphenol levels, and caseins and whey proteins (Zivkovic et al., 2009; Zulueta et al., 2009).

The evaluation of polyphenols showed that great variability existed between the levels determined for each group (Table 1, Figure 2 A and B). The SMP had a lower content of polyphenol than the WMP or IFP (SMP vs. WMP, $P \leq 0.04$; SMP vs. IFP, $P \leq 0.03$ ).

Radical scavenging capacity was significantly different for WMP compared with the blank ( $87 \pm 11$ vs. 100 $\pm 5 \% ; P \leq 0.04)$. The SMP had no radical scavenging capacity, as measured by the DPPH procedure. The IFP samples also displayed no radical scavenging capacity when analyzed as a group, as a result of great variability of individual samples. These results did not indicate a relationship between polyphenol content and radical scavenging capacity of MP.

\section{Relationships of Protein Oxidation and Antioxidant Capacity with Composition and Quality Parameters}

Multiple correlation analyses were used to determine if parameters were associated. When all possible pairs of variables were tested for correlations, we found that 4 were correlated: PC, WP, aggregates, and dispersibility (Table 2). The best correlations were found for $\mathrm{PC}$ with WP and for WP with dispersibility. It is interesting to note that these correlations comprised all 15 samples, so we could hypothesize that the PC content and dispersibility were governed by the content of WP, independently of the type of milk powder considered. This finding is in line with other reports because milk WP are known to be more susceptible to oxidative modifications than caseins, particularly $\beta$-lactoglobulin (Singh and Creamer, 1991; Scheidegger et al., 2010). Consequently, samples of milk powder with higher proportions of WP would display higher values of PC. The direct correlation between WP content and total carbonyl content $(P<0.002$, Table 2$)$, suggests that, on a total protein basis, WP were contributing to total carbonyl level more than casein. Support for this presumption is given by the higher content of whey proteins in IFP than in WMP and SMP (Table 1).

The level of aggregates in the samples was negatively correlated with dispersibility $(P=0.016, \mathrm{r}=-0.74$; Table 2). The reconstitution rate of milk powders depends on the succession of different steps: wettability, sinkability, dispersibility, and finally, solubility (MurrietaPazos et al., 2011). The presence of denatured proteins
A

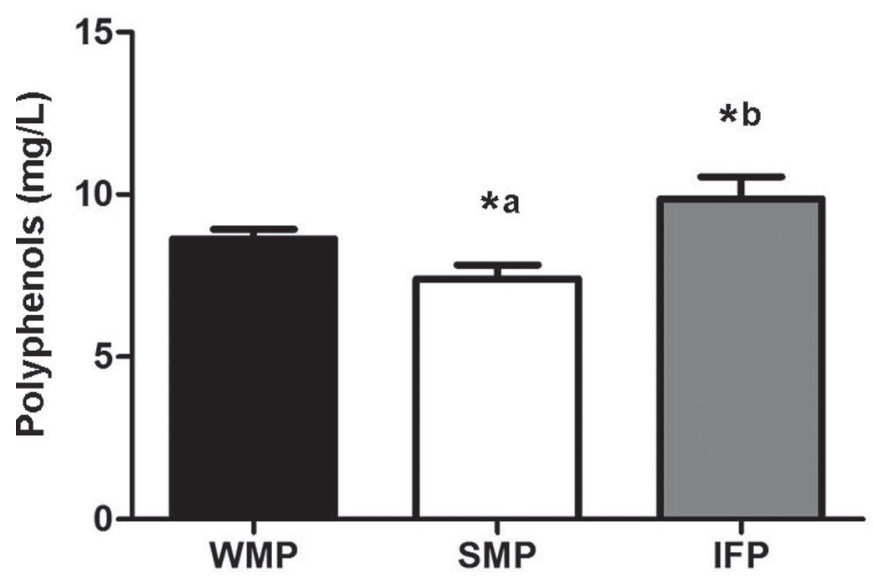

B

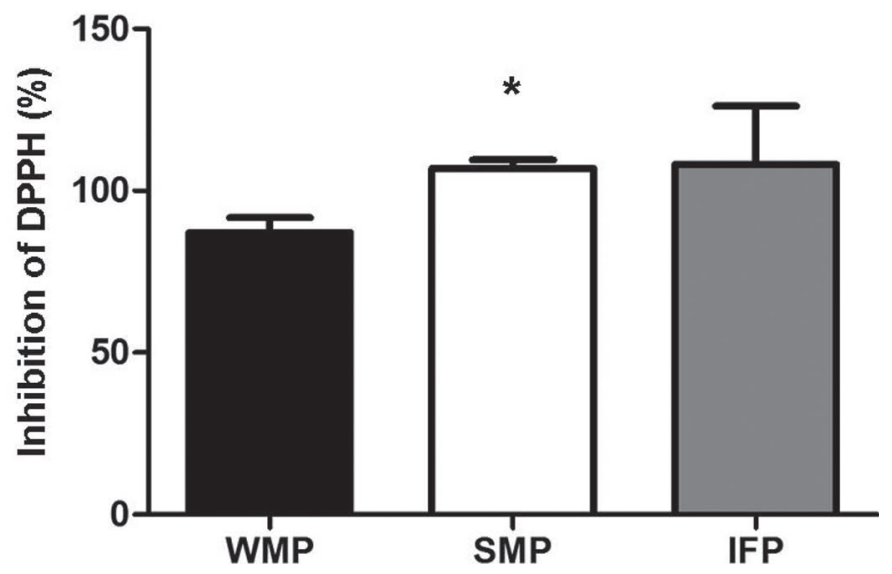

Figure 2. Antioxidant capacity of whole (WMP, $n=6)$, skim (SMP, $n=4)$, and infant formula (IFP, $n=5)$ milk powders: $(A)$ polyphenol content, and (B) radical scavenging capacity. Polyphenols were determined by a colorimetric technique and expressed as milligrams of gallic acid equivalents per $1,000 \mathrm{~mL}$ of sample. Radical scavenging capacity was measured as the percentage inhibition of 2,2-diphenyl-1-picrylhydrazyl $(\mathrm{DPPH})$ free radical formation (values higher than 100\% indicate pro-oxidant activity). Analysis of variance and a $t$-test were used to determine

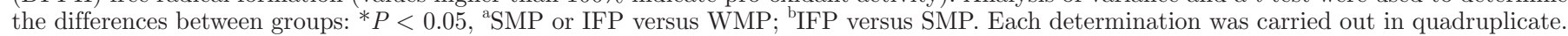


Table 2. Relationships of protein oxidation and antioxidant capacity with composition and quality parameters

\begin{tabular}{|c|c|c|c|c|c|}
\hline \multirow[b]{2}{*}{ Item $^{1}$} & \multicolumn{5}{|c|}{ Statistical parameter ${ }^{2}$} \\
\hline & a & $\mathrm{b}$ & $P$-value & $\mathrm{r}$ & $\mathrm{n}$ \\
\hline PC vs. WP & $2.1 \pm 0.4$ & $29 \pm 2$ & 0.0002 & 0.59 & 15 \\
\hline PC vs. aggregates & $0.4 \pm 0.1$ & $1.6 \pm 0.4$ & 0.002 & 0.73 & 15 \\
\hline PC vs. dispersibility & $-1.9 \pm 0.5$ & $93 \pm 2$ & 0.002 & -0.71 & 15 \\
\hline PC vs. polyphenols & $0.4 \pm 0.1$ & $7.1 \pm 0.5$ & 0.003 & 0.71 & 15 \\
\hline WP vs. aggregates & $3.0 \pm 1.1$ & $28 \pm 4$ & 0.020 & -0.61 & 15 \\
\hline WP vs. dispersibility & $-0.6 \pm 0.2$ & $110 \pm 8$ & 0.0010 & -0.64 & 15 \\
\hline WP vs. color (b) & $-0.15 \pm 0.04$ & $23 \pm 1$ & 0.002 & -0.74 & 15 \\
\hline Aggregates vs. dispersibility & $-3.1 \pm 1.1$ & $95 \pm 4$ & 0.016 & -0.74 & 15 \\
\hline
\end{tabular}

is detrimental to wettability (Millqvist-Fureby et al., 2001; Sliwinski et al., 2003); therefore, the finding that milk powders with higher contents of PC, aggregates, and WP were more difficult to disperse could indicate higher levels of denatured protein.

We also observed a significant correlation for $\mathrm{PC}$ as a function of total polyphenol content $(P<0.003, \mathrm{r}=$ 0.71; Table 2). Polyphenolic compounds have powerful antioxidant effects in vitro in many test systems, but can act as pro-oxidants in others (Halliwell, 2007). It has been reported that tea catechins contribute to the formation of protein carbonyl in human serum albumin (Ishii et al., 2010). The relationship between polyphenol content and carbonyl content of milk proteins has not been addressed yet, although the direct correlation between protein carbonyl content and the polyphenol content in milk powders in the current study suggests that mechanisms similar to those operating in the case of human serum albumin and polyphenols could be operating. Also, there are no reports in the literature that relate radical scavenging activity and polyphenol content, probably because this relationship is null, as we found in the current analysis. In an extensive study with edible plants, the relationship between phenolic content and radical scavenging activity was found in only some species (Wojdylo et al., 2007). Those authors concluded that the correlation was found only when phenolic compounds were the major contributors to antioxidant capacity. Milk contains several antioxidant factors: naturally occurring vitamins (i.e., E and C), $\beta$-carotene, enzymatic systems, serum albumin, and lactoferrin, which act as chelating agents, an ironbinding glycoprotein, as well as free radical scavenging activity by amino acids, such as tyrosine and cysteine (Pihlanto, 2006); thus, polyphenolics may not be the main contributors to antioxidant capacity.

Finally, the negative correlation between color (b) and WP $(P<0.002, \mathrm{r}=-0.74$; Table 2$)$ could be due to the higher content of late-stage Maillard products in milk powders with lower WP content (Thomsen et al., 2005).

\section{Effect of Storage Conditions on Protein Oxidative Status, Dispersibility, and Color}

All milk samples were analyzed after 9 mo of storage at $-20^{\circ} \mathrm{C}(\mathrm{CS})$ or room temperature (WS) to evaluate changes in protein oxidative status (PC, dityrosine, and protein integrity) as well the closely related parameters dispersibility and color. Figure 3 shows the changes observed. The content of PC was one of the most affected parameters: values observed after 9 mo were almost twice the initial values (Figure 3, panel A). The content of $\mathrm{PC}$ increased compared with the initial values in all tested samples (WMP and SMP: $P \leq 0.05$ for CS and $P$ $\leq 0.01$ for WS; IFP: $P \leq 0.001$ for CS and WS).

Dityrosine formation did not increase significantly after 9 mo, regardless of storage conditions, when compared by groups for the same type of milk powder $(6,4$, or 5 pairs for WMP, SMP, and IFP, respectively; Figure 3 , panel B). In contrast, when the 15 samples were analyzed as pairs before and after storage, a significant difference was found $(P=0.0292$ and $P=0.0186$ for CS and WS, respectively).

Stored milk powders had decreased dispersibility compared with initial values (WMP and IFP: $P \leq 0.01$ for CS; IFP: $P<0.05$ for WS; SMP: $P<0.05$ for CS, $P<0.01$ for WS; Figure 3, panel C). The evaluation of the 15 samples as 2 paired groups using Student's $t$-test showed that the reduction was $17 \%$ after CS and $9 \%$ after WS $(P=0.0002$ and $P=0.0007$, respectively).

We observed no changes in color when samples were grouped by type of milk powder (Figure 3, panel D), or when all 15 samples were subjected to paired $t$-test.

When analysis was performed with samples grouped by milk powder type, the amount of casein evaluated by SDS-PAGE was decreased only in IFP after storage $(P=0.0192$ and $P=0.0072$ for $\mathrm{CS}$ and $\mathrm{WS}$, respec- 
A

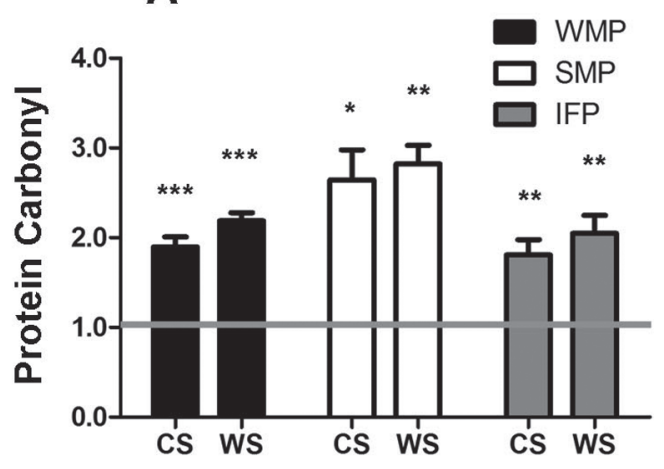

C

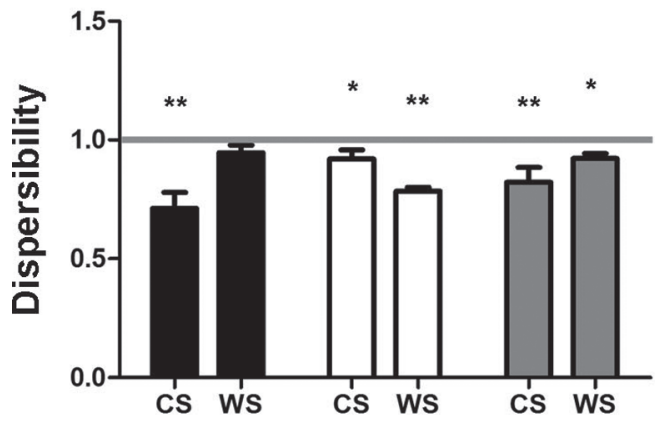

$E$

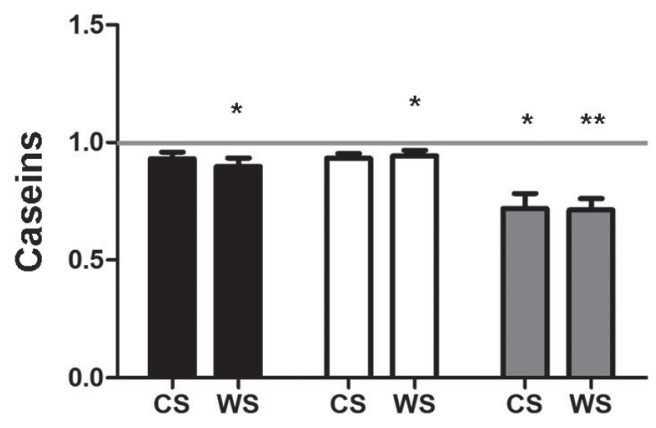

G

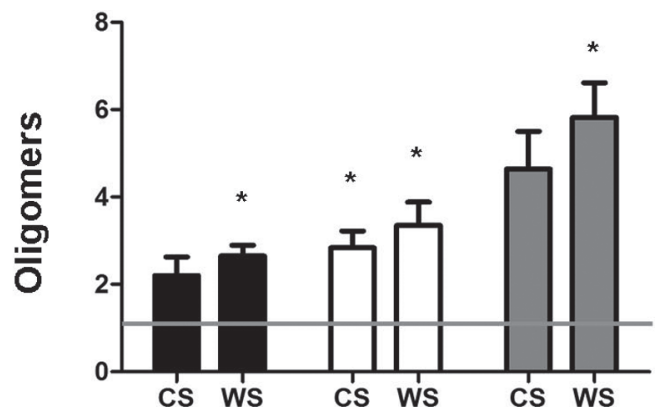

B

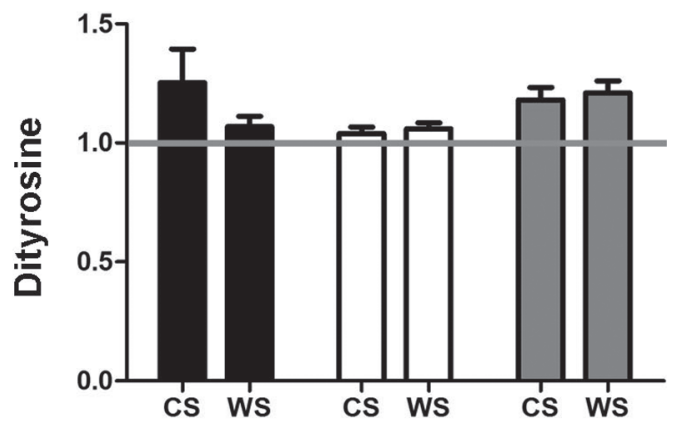

D

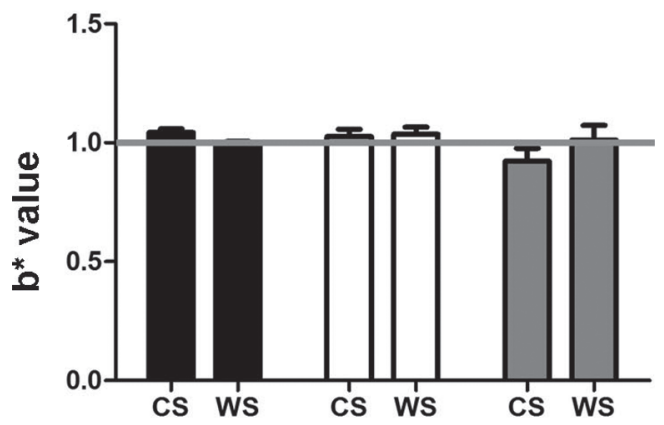

$\mathbf{F}$

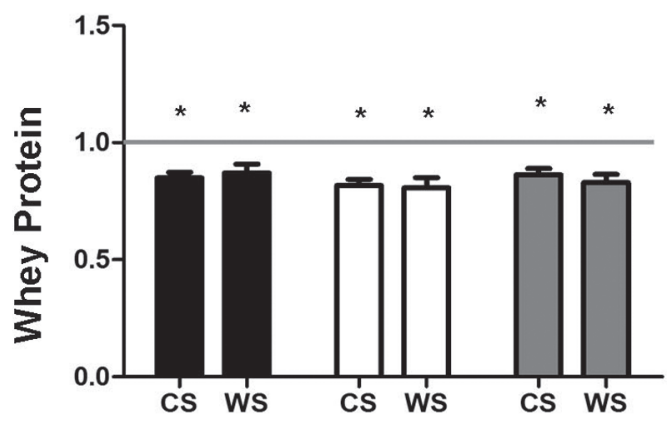

H

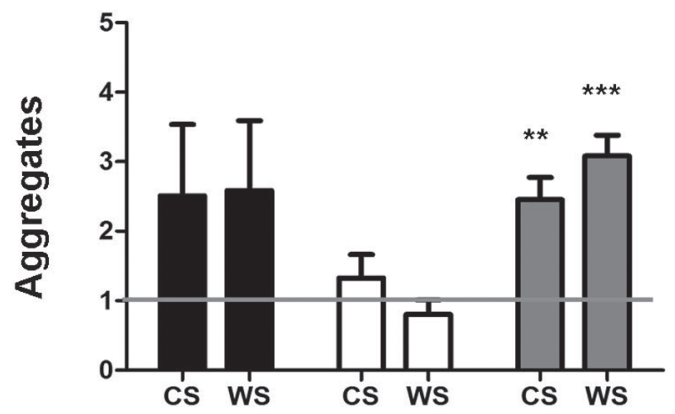

Figure 3. Effect of storage conditions on protein carbonyls, dispersibility, color, and protein integrity: (A) protein carbonyl, (B) dityrosine, (C) dispersibility, (D) color, (E) casein, (F) whey protein, $(\mathrm{G})$ protein oligomers, and (H) protein aggregates. Milk powder samples were stored at $24^{\circ} \mathrm{C}$ (warm storage, WS) or $-20^{\circ} \mathrm{C}$ (cold storage, CS) for 9 mo in the dark. Chemical analyses were performed as indicated in Figures 1 and 2 for initial conditions. Results were expressed as a ratio relative to the initial condition that was equal to 1 for each group (horizontal line). WMP $=$ whole milk powder, SMP = skim milk powder, and IFP = infant formula powder. Analysis of variance and a $t$-test were used to determine the differences between groups: ${ }^{*} P<0.05,{ }^{* *} P<0.01,{ }^{* * *} P<0.001$. Each SDS-PAGE gel was performed twice as independent experiments. 
tively; Figure 3, panel E). When a paired $t$-test was conducted with all the samples, we observed a decrease (mean of differences about 13\%: $P=0.002$ for CS and $P=0.0008$ for WS).

Whey protein decreased for all 3 groups $(P<0.05)$ after CS or WS (Figure 3, panel F). Paired Student's $t$-test (initial value vs. after storage for each sample) demonstrated that the reduction of all the samples grouped by storage condition was about 16\% (mean of differences: 15.5 and 16.8, $P<0.0001$, for CS and WS respectively).

We observed a significant increase in oligomers after CS only in SMP $(P<0.05)$. All samples maintained at room temperature had increased levels of oligomers $(P<0.05)$. Applying Student's $t$-test to a comparison of the whole population demonstrated that oligomer formation increased after CS $(211 \%)$ and WS $(282 \% ; P$ $=0.0023$ and 0.0009 , respectively).

Formation of aggregates increased significantly only for IFP after CS or WS $(P<0.05$; Figure 3, panel $\mathrm{H})$. When all the milk powder samples were analyzed together, we found a significant increase (mean increases of $133 \%$ and $167 \%$ after CS or WS compared with initial values, respectively; $P<0.05)$.

To test if initial conditions influenced the deterioration process after 9 mo of CS or WS, we performed a correlation analysis. We observed that the only parameter with a significant correlation was $\mathrm{PC}(P<0.0001$, $r>0.84$ ).

After 9 mo of storage, all tested parameters changed, indicating that milk powder quality had diminished regardless of type of powder and storage conditions. Differences in PC were the most significant changes observed, and PC content was the only parameter that showed a correlation with initial conditions, indicating that the initial level influenced the increase after storage. Moreover, because PC was strongly correlated with dispersibility and aggregate formation (Table 2), the reduced ability of powders in these parameters was predictable.

\section{CONCLUSIONS}

We concluded that milk powders of local origin had a low level of protein oxidative status and that SMP were less oxidized but had less antioxidant capacity than WMP. Finally, IFP presented a broad spectrum of oxidative status and anti- and pro-oxidant capacity. The most important finding was that 4 of the tested parameters were closely linked: PC, WP, aggregates, and dispersibility. Thus, all 4 determinations (PC, WP, aggregates, and dispersibility) could be used as complementary tests to evaluate dairy powder quality. Our results indicated that a chemical oxidative characteristic
(PC) was related to physical quality parameters such as dispersibility or stability during storage and that specific processing strategies and storage conditions must be applied to different milk powders depending on initial WP and PC levels.

\section{ACKNOWLEDGMENTS}

We thank María Rita Afonso de Romano and David Speroni (both at Universidad Nacional de Villa María, Córdoba, Argentina) for English correction and Carlos Argaraña (Universidad Nacional de Córdoba, Argentina) for critical reading of the manuscript. Grant support was from SeCyT, Universidad Nacional de Córdoba; Instituto de Investigación de la Universidad Nacional de Villa María. DS is recipient of CONICETMinCyT-Córdoba (Córdoba, Argentina) scholarship as a student of the doctoral career.

\section{REFERENCES}

AOAC International. 2005. Official Methods of Analysis. 18th ed. AOAC International, Gaithersburg, MD.

Balestrieri, M., M. S. Spagnuolo, L. Cigliano, G. Storti, L. Ferrara, P. Abrescia, and E. Fedele. 2002. Evaluation of oxidative damage in mozzarella cheese produced from bovine or water buffalo milk. Food Chem. 77:293-299.

Barros, L., M.-J. Ferreira, B. Queirós, I. C. F. R. Ferreira, and P. Baptista. 2007. Total phenols, ascorbic acid, $\beta$-carotene and lycopene in Portuguese wild edible mushrooms and their antioxidant activities. Food Chem. 103:413-419.

Besle, J. M., D. Viala, B. Martin, P. Pradel, B. Meunier, J. L. Berdagué, D. Fraisse, J. L. Lamaison, and J. B. Coulon. 2010. Ultraviolet-absorbing compounds in milk are related to forage polyphenols. J. Dairy Sci. 93:2846-2856.

Biolatto, A., G. Grigioni, M. Irurueta, A. M. Sancho, M. Taverna, and N. Pensel. 2007. Seasonal variation in the odour characteristics of whole milk powder. Food Chem. 103:960-967.

Birlouez-Aragon, I., M. Pischetsrieder, J. Leclère, F. J. Morales, K. Hasenkopf, R. Kientsch-Engel, C. J. Ducauze, and D. Rutledge. 2004. Assessment of protein glycation markers in infant formulas. Food Chem. 87:253-259.

Capeillere-Blandin, C., T. Delaveau, and B. Descamps-Latscha. 1991. Structural modifications of human beta 2 microglobulin treated with oxygen-derived radicals. Biochem. J. 277:175-182.

Carbonaro, M., F. Bonomi, S. Iametti, M. Cappelloni, and E. Carnovale. 1998. Aggregation of proteins in whey from raw and heatprocessed milk: Formation of soluble macroaggregates and nutritional consequences. Lebenson. Wiss. Technol. 31:522-529.

Dalsgaard, T. K., D. Otzen, J. H. Nielsen, and L. B. Larsen. 2007. Changes in structures of milk proteins upon photo-oxidation. J. Agric. Food Chem. 55:10968-10976.

Davies, M. J. 2005. The oxidative environment and protein damage. Biochim. Biophys. Acta 1703:93-109.

Fenaille, F., V. Parisod, P. Visani, S. Populaire, J.-C. Tabet, and P. A. Guy. 2006. Modifications of milk constituents during processing: A preliminary benchmarking study. Int. Dairy J. 16:728-739.

Gaiani, C., J. Scher, J. J. Ehrhardt, M. Linder, P. Schuck, S. Desobry, and S. Banon. 2007. Relationships between dairy powder surface composition and wetting properties during storage: Importance of residual lipids. J. Agric. Food Chem. 55:6561-6567.

Halliwell, B. 2007. Dietary polyphenols: Good, bad, or indifferent for your health? Cardiovasc. Res. 73:341-347. 
International Dairy Federation. 1979. Instant dried milk-Determination of the dispersibility and wettability: Reference method. FILIDF 087:1979. International Dairy Federation, Brussels, Belgium.

Ishii, T., T. Mori, T. Ichikawa, M. Kaku, K. Kusaka, Y. Uekusa, M. Akagawa, Y. Aihara, T. Furuta, T. Wakimoto, T. Kan, and T. Nakayama. 2010. Structural characteristics of green tea catechins for formation of protein carbonyl in human serum albumin. Bioorg. Med. Chem. 18:4892-4896.

Jovanovic, S., M. Barac, O. Macej, T. Vucic, and C. Lacnjevac. 2007. SDS-PAGE analysis of soluble proteins in reconstituted milk exposed to different heat treatments. Sensors (Basel) 7:371-383.

Kalapathy, U., N. Hettiarachchy, and K. Rhee. 1997. Effect of drying methods on molecular properties and functionalities of disulfide bond-cleaved soy proteins. J. Am. Oil Chem. Soc. 74:195-199.

Kurozawa, L. E., K. J. Park, and M. D. Hubinger. 2009. Effect of carrier agents on the physicochemical properties of a spray dried chicken meat protein hydrolysate. J. Food Eng. 94:326-333.

Laemmli, U. K. 1970. Cleavage of structural proteins during the assembly of the head of bacteriophage T4. Nature 227:680-685.

Levine, R. L., D. Garland, C. Oliver, A. Amici, I. Climent, A. Lenz, B. Ahn, S. Shaltiel, and E. Stadtman. 1990. Determination of carbonyl content in oxidatively modified proteins. Methods Enzymol. 186:464-478.

Lloyd, M. A., M. A. Drake, and P. D. Gerard. 2009. Flavor variability and flavor stability of U.S.-produced whole milk powder. J. Food Sci. 74:S334-S343.

Lüthi-Peng, Q., and Z. Puhan. 1999. Determination of protein and casein in milk by fourth derivative UV spectrophotometry. Anal. Chim. Acta 393:227-234.

Matumoto-Pintro, P. T., H. V. Petit, H. J. Giroux, C. Côrtes, N. Gagnon, and M. Britten. 2011. Effect of flaxseed lignans added to milk or fed to cows on oxidative degradation of dairy beverages enriched with polyunsaturated fatty acids. J. Dairy Res. $78: 111-117$

Millqvist-Fureby, A., U. Elofsson, and B. Bergenståhl. 2001. Surface composition of spray-dried milk protein-stabilised emulsions in relation to pre-heat treatment of proteins. Colloids Surf. B Biointerfaces 21:47-58.

Murrieta-Pazos, I., C. Gaiani, L. Galet, B. Cuq, S. Desobry, and J. Scher. 2011. Comparative study of particle structure evolution during water sorption: Skim and whole milk powders. Colloids Surf. B Biointerfaces 87:1-10.

Pihlanto, A. 2006. Antioxidative peptides derived from milk proteins. Int. Dairy J. 16:1306-1314.

Romeu-Nadal, M., J. L. Chávez-Servín, A. I. Castellote, M. Rivero, and M. C. López-Sabater. 2007. Oxidation stability of the lipid fraction in milk powder formulas. Food Chem. 100:756-763.
Scaloni, A., V. Perillo, P. Franco, E. Fedele, R. Froio, L. Ferrara, and P. Bergamo. 2002. Characterization of heat-induced lactosylation products in caseins by immunoenzymatic and mass spectrometric methodologies. Biochim. Biophys. Acta 1598:30-39.

Scheidegger, D., R. P. Pecora, P. M. Radici, and S. C. Kivatinitz. 2010. Protein oxidative changes in whole and skim milk after ultraviolet or fluorescent light exposure. J. Dairy Sci. 93:5101-5109.

Shimada, K., K. Fujikawa, K. Yahara, and T. Nakamura. 1992. Antioxidative properties of xanthan on the autoxidation of soybean oil in cyclodextrin emulsion. J. Agric. Food Chem. 40:945-948.

Singh, H., and L. K. Creamer. 1991. Denaturation, aggregation and heat stability of milk protein during the manufacture of skim milk powder. J. Dairy Res. 58:269-283.

Singleton, V. L., and J. A. Rossi Jr. 1965. Colorimetry of total phenolics with phosphomolybdic-phosphotungstic acid reagents. Am. J. Enol. Vitic. 16:144-158.

Sliwinski, E. L., B. W. M. Lavrijsen, J. M. Vollenbroek, H. J. Van Der Stege, M. A. J. S. Van Boekel, and J. T. M. Wouters. 2003. Effects of spray drying on physicochemical properties of milk proteinstabilised emulsions. Colloids Surf. B Biointerfaces 31:219-229.

Stadtman, E. R., and R. L. Levine. 2000. Protein oxidation. Ann. N. Y. Acad. Sci. 899:191-208.

Stapelfeldt, H., B. R. Nielsen, and L. H. Skibsted. 1997. Effect of heat treatment, water activity and storage temperature on the oxidative stability of whole milk powder. Int. Dairy J. 7:331-339.

Thomas, M. E. C., J. Scher, S. Desobry-Banon, and S. Desobry. 2004. Milk powders ageing: Effect on physical and functional properties. Crit. Rev. Food Sci. Nutr. 44:297-322.

Thomsen, M. K., L. Lauridsen, L. H. Skibsted, and J. Risbo. 2005. Two types of radicals in whole milk powder: Effect of lactose crystallization, lipid oxidation, and browning reactions. J. Agric. Food Chem. 53:1805-1811.

Wojdyło, A., J. Oszmiański, and R. Czemerys. 2007. Antioxidant activity and phenolic compounds in 32 selected herbs. Food Chem. 105:940-949

Zivkovic, J. V. S. M. Sunaric, N. V. Trutic, R. M. Pavlovic, G. M. Kocic, G. S. Nikolic, and T. V. Jovanovic. 2009. DPPH radicalscavenging activity of pasteurized cow milk. Mleko i mlecni proizvodi $20: 45-47$

Zulueta, A., A. Maurizi, A. Frígola, M. J. Esteve, R. Coli, and G. Burini. 2009. Antioxidant capacity of cow milk, whey and deproteinized milk. Int. Dairy J. 19:380-385. 